\title{
Creative and knowledge-intensive teleworkers' relation to e-capital in the Helsinki metropolitan area
}

ARTICLE in INTERNATIONAL JOURNAL OF KNOWLEDGE-BASED DEVELOPMENT · JANUARY 2013

3 AUTHORS:

Maria Merisalo

University of Helsinki

6 PUBLICATIONS 0 CITATIONS

SEE PROFILE

Tommi Inkinen

University of Helsinki

35 PUBLICATIONS 67 CITATIONS

SEE PROFILE
Teemu Makkonen

University of Surrey

21 PUBLICATIONS 17 CITATIONS

SEE PROFILE 
Creative and knowledge-intensive teleworkers' relation to e-capital in the Helsinki Metropolitan Area

\author{
Maria Merisalo \\ Department of Geosciences and Geography, \\ University of Helsinki, \\ PO Box 64, FI-00014, Finland \\ E-mail: maria.merisalo@helsinki.fi
}

\title{
Teemu Makkonen
}

Department of Geosciences and Geography,

University of Helsinki,

PO Box 64, FI-00014, Finland

E-mail: teemu.makkonen@helsinki.fi

\section{Tommi Inkinen}

Department of Geosciences and Geography,

University of Helsinki,

PO Box 64, FI-00014, Finland

E-mail: tommi.inkinen@ @elsinki.fi

This is an Accepted Manuscript of an article published by Inderscience in International Journal of Knowledge-Based Development on August 14, 2013, Vol. 4, No. 3, pp. 204-221. Available online: http://dx.doi.org/10.1504/IJKBD.2013.055870 
Biographical notes:

Maria Merisalo is a PhD student at the Department of Geosciences and Geography, University of Helsinki. She is currently pursuing her Doctorate degree in the area of human geography.

Teemu Makkonen is currently a PhD student at the Department of Geosciences and Geography, University of Helsinki. He is currently pursuing his Doctorate degree in the area of economic geography.

Tommi Inkinen, $\mathrm{PhD}$, is currently a Professor of Human Geography at the Department of Geosciences and Geography at the University of Helsinki, Finland. He also holds Docentships of Regional Studies and Economic Geography. His research interests primarily cover the issues of economic and human geography, including the regional and social structuring of innovation systems, technology, regional development, as well as logistics and transport. He is a steering group member of the International Geographical Union's (IGU) Global Information Society Commission and Editor-In-Chief of peer-reviewed quarterly journal Terra, Finnish Geographical Journal.

\begin{abstract}
This paper examines the extent to which teleworkers in the Helsinki Metropolitan Area (HMA) fit the profile of knowledge or creative workers. Furthermore, the concept of electronic capital (e-capital), referring to the use of ICT, electronic services and social media, is redefined and applied in relation to teleworkers. The data were gathered through a stratified postal survey $(n=971)$ conducted in the HMA in 2010. Statistical testing indicated no difference in terms of knowledge intensity, creativity and e-capital between 'home-anchored' workers and mobile or part-time teleworkers. However, a significant difference was noted between teleworkers and non-teleworkers. The results reveal the complexity of telework in both a theoretical and empirical context. The paper also points to the significance of e-capital in relation to telework, networking and the creating and maintaining of social relations, supporting the theoretical proposition of e-capital.
\end{abstract}

Keywords: Helsinki Metropolitan Area, Social media, Knowledge, Telework, Electronic capital, Social capital, Human capital 


\section{Introduction}

Technologies, including wireless and bandwidth networks, provide a convenient, open and global link for workers to communicate with their central offices from distant locations. The development of ICTs has increased the demand for knowledge resources and has enabled greater employee autonomy (Dimitrova, 2003). The relative ease of obtaining and using information has led to radical shifts in both organizational structures and individuals' work methods (Harpaz, 2002). This has changed the spatial and temporal structures of work (Bèlanger and Allport, 2008). In line with this shift in working life is also an evident growth in the use of information and communication technologies (ICTs) in other daily routines that are not related to work. The numerous applications in social media have recently increased the possibilities to network via the Internet in and outside the realm of working life. These increased opportunities should also have an impact on individuals, as people at ease with these abilities will gain an advantage compared to those who are not. The concept of electronic capital (e-capital) is applied and redefined as the possibility, ability and willingness to use ICT, electronic services and social media resulting in benefits to the users, the economy and society.

Various definitions of telework are commonly applied in the analyses of technology and labour market change, as they are dependent on technological development having socio-economic implications concerning individuals, organizations and societies (Ellison, 1999; Pyöriä, 2003). Telework has inspired academic research from the early 1970s onward (see Bailey and Kurland, 2002). Already in the early 1980s, Toffler (1980) suggested 'electronic cottages' as a solution to the transportation crisis experienced by most high-technology nations. Toffler's views triggered a growing interest in the phenomenon (Cooper and Kurland, 2002; Haddon and Brynin, 2005; Mann and Holdsworth, 2003). However, the long and rich history of research into telework has 
not produced a single universally agreed definition. Academics and scholars have varying ways to conceptualize and analyse telework. In light of this debate, our paper recognizes the ambiguity associated with concept of telework and adopts the term of 'home-anchored' work alongside the more traditional definitions. However, the brief summary of Kurland and Egan [(1999), p.500] is still relevant today: 'telework is a work design that liberates one from time and space, in which work is an activity, not a place'.

The research question this paper asks is related to the knowledge and creativity functions of telework, and teleworkers' use of ICT, the current concept of social media in particular. An assumption that creative and knowledge workers are the primary candidates for teleworking is made: the paper examines to what extent teleworkers in the Helsinki Metropolitan Area (HMA), Finland, fit the profile of creative and knowledge workers, who are essential for the competitiveness of cities (Florida, 2002; Harmaakorpi and Melkas, 2005). The question is interesting because, despite their similarities, there seems to be a mismatch between the definitions of these concepts. Moreover, there are cases, in which teleworkers are more likely to be routine workers than knowledge workers. It has also been argued that knowledge work actually limits the opportunity to telework (Bentley and Yoong, 2000). This has partially led to the elusiveness of the idea of teleworking, evident by the fact that fewer people actually telework compared to predictions (Cooper and Kurland, 2002) that envisioned it as an important new element of the market economy and providing solutions to a spectrum of policy issues. These envisioned benefits of telework range from the mitigation of air pollution and global warming to gains in productivity and the economic development of cities and regions (Bélanger and Collins, 1998; Harpaz, 2002). The relevance of studying teleworkers' e-capital is founded on the relation between both ICT and telework (e.g. Dimitrova, 2003; Toffler, 1980) and 
knowledge work (e.g. Pyöriä, 2006). The present study examines this connection not only by examining more traditional ICT forms, but also by combining new social media applications in order to produce new insights on ICT use in relation to the realm of working life and society.

\section{Conceptual framework}

Defining telework and knowledge work

The various definitions of telework are the subject of ongoing debate (Harpaz, 2002; Pyöriä, 2003; Wilks and Billsberry, 2007). Telework is most often defined as combining location, technology and time as a platform for work which is done outside the primary (fixed) work location (excluding overtime work). Teleworking has changed the location-bound condition of work: fixed premises are not necessary for knowledge-intensive work (Bélanger and Allport, 2008). ICT has been a significant factor transforming work towards greater flexibility, responsiveness and effectiveness (Baruch, 2000). In fact, the greater adaptability of work has led to more flexible working hours, and traditional time limitations have lost their significance. Other terms including home, remote, distance and flexible work have also been used to describe similar location-free arrangements (Lai and Burchell, 2008; Sullivan, 2003; Whittle and Mueller, 2009). For the present study, the reference groups (surveyed teleworkers) are as follows (also Ellison, 1999):

(1) Home-anchored teleworkers

(2) Mobile (part-time) teleworkers

The rationale behind this schema is derived from Wilks and Bilssberry (2007), who question the value of labelling part-time or mobile teleworkers as 'proper' teleworkers. As such a division 
refers to the location and time dimensions of telework, Wilks and Bilsberry [(ibid.) p.176] recognize the transfer of the locational anchor of working life from traditional offices to the home as the most useful and consistent distinguishing feature of telework, because homeanchored work excludes those who 'split their time between home and a traditional office' (also Laegran, 2008). However, Thomsin and Tremblay (2008) have noted similarities between telework and mobile work, as telework, in the traditional sense, appears to be moving in the direction of mobility. Furthermore, the dimension of time has not been prevalent in the most commonly used telework definitions. Therefore the exclusion of part-time and mobile work from telework is debatable.

The same ambiguity arises from the concept of 'knowledge worker': there is no consensus on the definition (Alvesson, 2001; Pyöriä, 2005). Still, knowledge workers are usually understood as workers who use ICT, have a relatively high level of formal education, work autonomously and are often required to work in teams. 'Knowledge intensity' of work is examined in the present study through five factors (also Pyöriä, 2006):

(1) Use of information and communication technology

(2) Independence of the work

(3) Educational level

(i) The notion that along with extensive education, knowledge work also requires diverse cultural skills is acknowledged, but here the main interest is in formal education

(4) Teamwork and social interaction

(5) Flexible working hours 
Telework and knowledge work share a close connection with each other in conceptual terms. It may be argued that the connection between knowledge work and telework can be seen in opposite ways. The first supports the close link between the two and claims that knowledge workers are the primary candidates for teleworking (Bélanger and Allport, 2008; Bélanger and Collins, 1998; Handy and Mokhtarian, 1996; Lee et al., 2007). Indeed, Daniels et al. (2001) argue that knowledge intensity is actually a part of the general telework framework.

Directly opposite to the first view, the second states that telework is not related to knowledge work and that more routine workers are the primary candidates for teleworking. In fact, Bentley and Yoong (2000) claim that the nature of knowledge work actually limits the flexibility and choice that are associated with teleworking: the importance of collaboration, teamwork and the need for social interaction and proximity, which knowledge work is actually founded on (Pyöriä, 2003), runs counter to the basic idea of teleworking. Wilks and Billsberry (2007) have stated that a job's degree of knowledge orientation is of little value when identifying teleworkers. In addition, Chalmers (2008) has argued that the relationship between the use of information technologies and home-based production is stronger for employees in routine occupations than knowledge occupations. An implicit portrayals of offices as professional workplaces where all employees are knowledge workers - ignoring the diversity of office jobs and a lack of discussion about 'routine' teleworkers have been identified by Stanworth (1998).

We conclude with Richard Florida's (2002) idea of 'creative workers'. According to Florida (2005), creativity is the main factor driving the economy of cities. The notion has drawn a considerable amount of criticism (Markusen, 2006; Tremblay and Darchen, 2010), but the 
essential idea of creativity as a factor affecting the economy and society seems plausible, as the environment in which knowledge work is carried out is (often) highly creative (Pyöriä, 2006).

\section{Applying the concept of electronic capital}

Our paper applies and redefines the concept of e-capital. Hall (2000) used the term in relation to college graduate workers' use of business methods based on computers. However, acknowledging the motivation, skill and accessibility factors related to ICT use (van Deursen et al., 2006), here e-capital refers to the possibility, ability and willingness to use ICT, electronic services and social media, resulting in benefits to the users, the economy and society. We acknowledge an overlap of the conceptual definitions of ICTs, electronic services and social media: we apply them to portray the wide range and fast pace of recent technological change including established technologies and new applications. We follow Rust and Kannan (2002), and define electronic services as the 'provision of service over electronic networks'. Furthermore, the study adopts Lietsala and Sirkkunen's [(2008), p.13] definition of social media: 'social media is a term used to describe web services that receive most of the content from their users or that aggregate the content from other sites as feeds'. In the empirical part of the study, 'ICT' in general will refer to laptop computers, the internet and email, as well as electronic services and social network sites (LinkedIn, Facebook, Twitter) together with blogs and discussion forums.

E-capital is related to other forms of capital, as suggested by Bourdieusian neo-capital theory, where both intangible and tangible forms of capital are seen as being continuously accumulated, constructed and converted in social actions (Svendsen et al., 2010). The theory suggests that individuals can invest and thus acquire certain capital of their own, as well as generate surplus 
values in offering their work and services on the production and consumption markets (Lin, 1999). Thus the convertibility of the different types of capital is the basis of one's position in social space (Bourdieu, 1986).

In our definition of e-capital, possibility relates to physical and economic capitals, which are the traditional and tangible forms of the concept. Bourdieu (1986) argues that economic capital is the basis of capital's other forms. Thus we consider that infrastructure and material resources are prerequisites for the development of e-capital. In practice, people need the hardware (i.e. laptops, smartphones), software (i.e. browsers, e-mail accounts) and internet connections (Graham, 2011), and investments are needed to build information infrastructure and to buy the hardware or online connections.

The concept of human capital was originally (e.g. Shultz, 1961) described as the knowledge and skills that individuals acquire through education and training. However, our study validates the discussion of human capital through education, it being the most commonly used indicator of human capital (Teixeira and Fortuna, 2010). In our definition of e-capital, human capital is related to ability to use ICT, electronic services and social media. This is in line with the idea that education and human capital are highly related to ICT use (e.g. Arvanitis and Loukis, 2009; Graham, 2011; Wei, 2012). Furthermore, Florida et al. (2008) have identified a relationship between technology and talent, one of the topics under scrutiny in this study.

Willingness, according to our definition of e-capital relates to cultural capital of tastes, choices, life-styles and culture-based practices (Bourdieu, 2010; cf. Jung et al., 2001). Thus attitudes and goals in the specific contexts of technology use relate to cultural capital that can be turned into 
other forms of capital, such as financial or social (Jung et al., 2001). Technology use and techno-culture are shaped by friends, peers and techno-cultural goods (Selwyn, 2004). Different groups possess different amounts of cultural capital, which results in unequal opportunity with respect to the use of internet resources (Jung et al., 2001). Bourdieu (1986) argues that to acquire machines individual only needs economic capital but to use them in accordance with their specific purposes he must have access to cultural capital (also Selwyn, 2004). Thus ICT use can be seen as a contemporary indicator of cultural capital (Tondeur et al., 2011).

E-capital is also related to social capital. Social capital is a fluid concept that lacks consensus on a single definition. Bourdieu [(1986), p.248] defines it as the 'aggregate of the actual or potential resources which are linked to possession of a durable network of more or less institutionalized relationships of mutual acquaintance and recognition'. Like other forms of capital, social capital is productive, enabling the achievement of certain ends that in its absence would not be possible (Coleman, 1988), and enhancing the benefits of investment in physical and human capital (Putman, 1993). The use of social media has therefore proved to be related to social capital (e.g. Ellison et al., 2007). Mandarano et al. (2010) show that social networking sites (SNSs) have great potential to produce a new form of a social capital: 'digital social capital' (cf. Resnick, 2001). Furthermore, Steinfield et al. (2008) have found a connection between social capital and Facebook use: they argue that greater use of Facebook would result in greater social capital. Also [Lietsala and Sirkkunen (2008), p.14] argue that social media 'participants gain use value as a result of community action'. Social media is a profitable business, and provides advertising possibilities and income for firms. It also has an impact on the social relations and well-being of individuals. The importance of social capital for knowledge work (including telework) has been identified by Lorenzen (2007), who argues that 
social capital may be seen as society's most basic social infrastructure providing knowledge and skills highly conducive to technological learning. The transition between e-capital and social capital is bidirectional, as Bourdieusian neo-capital theory suggests. Furthermore, social capital is important for economic growth and regional development (Beugelsdijk and Van Schaik, 2005; Iyer et al., 2005; Tura and Harmaakorpi, 2005) and a decisive factor in effective regional innovation networks (Rutten and Boekema, 2007).

\section{Synthesis}

The rationale behind studying e-capital in relation to telework may be found in a wide range of studies that have revealed a connection between ICT and teleworking/knowledge work (e.g. Lai and Burchell, 2008; Haddon and Brynin, 2005; Pyöriä, 2006). The present study contributes to understanding ICT use in relation to telework. The role of ICT is essential, because it facilitates and maintains teleworkers' links to a central office or network (e.g. Sullivan, 2003). Accordingly, Dimitrova [(2003), p.181] states that teleworkers 'use computers, laptops, and communication technology to do their work outside the traditional office'. Along with ICTrelated knowledge, the workers must possess other individual skills, including self-sufficiency and communication abilities, in order to enable distributed work arrangements to function satisfactorily for both the employee and the employer (Bélanger and Collins, 1998). Additionally, the very organization of knowledge work takes place in electronic media, thus eroding the need for spatial consolidation (Yigitcanlar et al., 2007). Pyöriä (2006) states that the level of the use of ICT, educational level, social interaction and teamwork are admitted indicators of knowledge work. 
Thus it is argued that (knowledge-intensive) teleworkers are distinct from other working groups on the basis of their knowledge intensiveness and creativeness, educational level as well as ICT and social media use. These conceptual insights provide the literature-based foundations for the paper's main research question: How do teleworkers (home-anchored versus mobile and parttime) differ in knowledge intensiveness and creativeness, educational level, and ICT and social media use compared to non-teleworkers?

This question is examined through data collected from the HMA, where the ICT sector has acted as the primary engine of growth since the 1990s (Vaattovaara and Kortteinen, 2003). Moreover, in Finland both knowledge work and telework are concentrated in large urban areas, the HMA being the leading example (Helminen and Ristimäki, 2007; Kepsu and Vaattovaara, 2008), further justifying its use as the case study region.

\section{Data and methods}

The data were gathered by a stratified postal survey conducted in the HMA in 2010, as a part of the larger 'Information society survey of the Helsinki Metropolitan Area'. Its aim was to shed light on differences in the uses of ICTs, e-services, social media and telework in three different types of regions within the HMA. The total sample size was 2500 persons. Altogether 971 forms were returned making the response rate a satisfactory 39\% (Appendix 1). The three regional types were conceived from 16 districts on the basis of Statistics Finland data on educational and income levels, ownership of housing and proportion of apartment blocks (Table 1). The aim was to depict regions clearly different from each other, and provide a representative description of different types of residential areas within the HMA: 
(1) City centre, representing a medium sized European city centre

(2) Detached house area (educated middle class)

(3) Apartment block area (rental apartments and lower educational and income levels)

\section{TABLE 1 ABOUT HERE}

The analysis is based on comparisons between the following groups: 33 home-anchored workers, 180 mobile or part-time teleworkers and 637 non-teleworkers (uncertain respondents and those not involved in working life in the past two years were excluded from the sample). The respondents were asked to identify whether they are able telework or not (Bélanger, 1999). The form identified several forms of telework for respondents: For example, home-anchored workers were separated from the rest of the teleworkers by place and time measures: mobile teleworkers and those teleworking less than three days a week were excluded from the group of home-anchored workers.

Standard statistical tests were applied: a Mann-Whitney U-test was used as an analytical tool to evaluate the differences between these groups. The test is a nonparametric substitute for the two-sample t-test, i.e. a normally distributed population is not a prerequisite. However, it requires at least ordinal variables, a continuous population and a random sample from the respective population (Gravetter and Wallnau, 2008; Kirk, 2008): the data met these preconditions. The null hypothesis of the test was that the distributions of the two populations are identical. In the analysis, a sum variable (means) was constructed from a set of questions where respondents were asked to evaluate statements on a scale from 1 (lowest score) to 5 
(highest score) related to the knowledge intensiveness and creativity of their work descriptions. The statements were as follows:

(1) I do my work mainly with a computer.

(2) I need an ability to make independent decisions in my work.

(3) Social interaction skills are important in my work.

(4) My work is independent.

(5) Teamwork is an essential part of my work.

(6) My work requires flexibility (related to e.g. working hours).

(7) My work requires creativity.

Educational level is one of the elements of knowledge intensity (Alvesson, 2001; Pyöriä, 2005): the relationship between telework and education was analysed by chi-square test (used here as a test of independence). The null hypothesis of the test is that there is no significant relationship between these two variables. The chi-square test is non-parametric, based on the notion of probability addressing statistical significance. The test involves comparing the observed values to the expected (with no association) values (Cohen et al., 2007; Gravetter and Wallnau, 2008). This enabled us to draw conclusions about the similarities (or dissimilarities) between the studied variables.

Chi-square tests were also used to study the relationship between telework and the use of ICT and social media. That is to say, e-capital was examined through nine variables including both established technologies and more recent applications (see also Table 3). Here, the use of the Internet, email and laptops represent established technologies. The use of these technologies has 
been shown to be closely related to teleworking (Dimitrova, 2003). Six variables were used to represent attributes associated with the use of social media. The first two are related to the use of social network sites (SNSs) in general and the reasons for professional networking. The following three variables consider the use of certain social media. The distinct e-services were selected because of their prevalent market position. The final variable considers the use (reading, following and providing the content) of Internet forums. The proportion of tertiaryeducated persons was applied as the measure of the workers' educational level.

\section{Results}

The proportion of home-anchored workers was only about $4 \%$ of the total number of respondents included in the analysis. Thus the findings from previous studies in Finland (Pyöriä, 2003; 2006) are verified by the data: full-time teleworking is still rare in Finnish society. However, when considering the broader definitions of telework, i.e. when mobile and part-time teleworking is included, the proportion of teleworkers increased to $25 \%$. This figure is quite close to the proportion of knowledge and creative workers in the HMA, as described by Kepsu and Vaattovaara [(2008), p.11]: 'in the Helsinki Metropolitan Area 30.5 percent of the employees work in the sectors...defined as being creative knowledge sectors', pointing towards a close link between telework, knowledge and creativity.

The reliability of the sum variable of knowledge intensity and creativity of the workers was estimated by a Cronbach's $\alpha$-test (0.626). It indicated that the constructed sum variable worked reasonably well in describing the knowledge intensity and creativity of the workers. Somewhat surprisingly, the question number one concerning computer usage, was actually an item that impaired the reliability of the sum variable. As discussed, although the workers' use of ICT is 
essential to both definitions (telework and knowledge work), it was strongly associated only with the statement concerning the independence of the work (corrected item-total correlation $=$ 0.221) due to its divergent distribution. However, as the use of ICT is important to the overall research question, a decision to include it in the sum variable was made.

The Spearman's chi-square and Mann-Whitney U- tests indicated no evident or statistically significant differences between education or knowledge intensity and creativity with respect to home-anchored workers as well as mobile and part-time teleworkers (Table 2; Figure 1). According to the sample, nothing set these two groups apart when considering the educational level or the sum variable of knowledge intensity and creativity. However, Table 2 and Figure 1 indicate statistically significant differences between teleworkers and non-teleworkers in relation to educational levels and their knowledge intensity and creativity. The analysis presents clear evidence of teleworkers having (in general) a higher educational level than non-teleworkers. Additionally, the Mann-Whitney U-test indicated that teleworkers are more knowledge intensive in their work (their work is independent including elements of creativity, their working hours are flexible as well as teamwork and social interaction is an important feature in their line of work) compared to non-teleworkers.

\section{TABLE 2 ABOUT HERE}

FIGURE 1 ABOUT HERE

Spearman's chi-square test revealed no statistically significant differences between homeanchored workers and mobile and part-time teleworkers in the nine measures used here to 
describe e-capital, i.e. the use of ICT and social media did not differ between these distinct teleworker groups (Table 3). Statistically significant differences were found in the use of ICT and social media between teleworkers and non-teleworkers (Table 3). The most fundamental difference between the groups can be observed in relation to the use social of networks for professional networking purposes: $56.8 \%$ of teleworkers compared to $26.6 \%$ of non-teleworkers used SNSs to network with work-related persons. The results show that not all SNSs attract teleworkers: Facebook in particular is commonly used by both groups. However, a fundamental difference between the groups exists in the use of LinkedIn service.

\section{TABLE 3 ABOUT HERE}

\section{Discussion}

The earlier notions (Bentley and Yoong, 2000; Wilks and Billsberry, 2007) of the incompatibility of telework and knowledge work are not supported by our survey from the HMA. The relationship between knowledge intensity and creative work on the one hand, and telework on the other, is statistically significant in our data. Thus the results support the claims that telework, knowledge intensity and creativity share common features, and that teleworkers are a fairly homogenous group in relation to these variables (Bélanger and Allport, 2008; Handy and Mokhtarian, 1996). The study notes that telework is not an occupation and that one has an opportunity to telework if the occupation in question enables it. This study points out that telework is a feature of knowledge-intensive and creative work, not the other way around. Furthermore, the data clarified that telework's place or time does not define teleworkers' knowledge intensity or creativity. However, we recognize that the situation is likely to differ 
according to normative and coercive factors including the legislation and policies of given country or a region (also Daniels et al., 2001).

The number of teleworkers in our data is significant (a quarter of the sample) if mobile and parttime teleworkers are also included. This indicates that although requiring a redefinition, earlier predictions of an increasing number of teleworkers have not been entirely wrong (see Cooper and Kurland, 2002; Pyöriä, 2003; Toffler, 1980). Additionally, telework has become a more part-time than full-time work arrangement, thus contradicting some of the advantages of telework as envisioned by Toffler (1980). The study therefore suggests that a division between home-anchored workers and mobile (and part-time) teleworkers is not very relevant. A more beneficial standpoint in future studies would be to fully explore the concept without constraining expectations of full-time (home-anchored) teleworking. This would also be worthwhile when considering the small sample size (only 33 respondents) of the strict time- and place-bounded delineation.

The working life of teleworkers and non-teleworkers differs substantially, as teleworking allows for a flexible way of arranging e.g. work schedules. The data suggest that a full-time physical presence in the workplace is not necessarily needed in suitable professions. In addition, telework does also involve collaboration, team work and social interaction (Pyöriä, 2003) as ICT works as a substitute for physical presence (e.g. teleconferencing).

The use of ICT and social media are related to teleworking and the analysis confirms several results of earlier studies (Dimitrova, 2003; Inkinen, 2006; Haddon and Brynin, 2005). The differences between the tested worker groups (teleworkers and non-teleworkers) indicate that 
certain assets of (knowledge-intensive and creative) teleworkers relate to the use of ICT and social media. This leads us to propose a theoretical consideration of e-capital. Further studies are apparently needed to examine the causality and theoretical background of the concept, as the present study indicated the significance of e-capital in relation to networking for business and professional reasons. Networking as well as creating and maintaining social relations have already been shown to have an impact on the economic performance of cities and regions (Beugelsdijk and Schaik, 2005; Iyer et al., 2005; Tura and Harmaakorpi, 2005). An interesting research endeavour would be to relate the notion of Mandarano et al. (2010) concerning digital social capital to e-capital, to gain a better understanding of the technological assets that are related to working life and economic performance.

A relationship exists between (knowledge-intensive and creative) teleworking and education, confirming Pyöriä's (2006) interpretation regarding the close relation between telework, knowledge intensiveness and creative work - and sparking interest in further studying the association between education and e-capital in terms of human capital theory. Earlier studies would seem to support this. For example, Hoyman and Faricy (2009) have recommended a clarification of the relationship between human and social capital and Iyer et al. (2005) have argued that education is important in nearly all indicators of social capital. Furthermore, Florida et al. (2008) have discussed the relationship between technology and talent, encouraging further clarification in this area (also Florida, 2005; Harmaakorpi and Melkas, 2005; Pyöriä, 2006). Moreover, the present study suggests that higher numbers of teleworkers within a region as well as higher levels of e-capital are associated with greater economic development and regional knowledge intensity (Komninos, 2002). 


\section{Final remarks}

We examined the questions of how teleworkers fit the profile of creative and knowledge workers, and how telework relates to the concept of e-capital. The analyses provided no statistically significant differences in knowledge intensity, creativity, educational level or ICT and social media use (e-capital) between the distinct teleworking groups. However, the teleworkers had higher educational levels as well as more knowledge-intensive and creative occupations compared to non-teleworkers. Moreover, the use of ICT and social media was more common among teleworkers than non-teleworkers.

The division of teleworkers into subgroups provided a problematic insight for understanding telework. Obtained results verified that telework is more a part-time than full-time arrangement. The situation is likely to differ regionally and comparative spatial research is needed. The homogeneity of teleworkers in terms of knowledge intensity, creativity and educational level indicates that the group has other common features. Furthermore, the conducted study revealed a connection between teleworking and the use of ICT and social media for business and professional reasons. This refers the potential benefits gained from ICT and social media use, highlighting the functionality of 'e-capital' concept. The study also indicates that e-capital is related to social and human capital, calling for further research on the characteristics of teleworkers to clarify the relevance of e-capital for cities and regions.

\section{Acknowledgements}

This article is a revised and expanded version of a paper entitled Telework, knowledge and creativity: Perceptions from the Helsinki Metropolitan Area (The 4th Knowledge Cities World Summit, Bento Concalves, Brazil). The authors thank Arttu Paarlahti for his help with the 
figures. The authors are grateful to anonymous reviewers for constructive and supportive comments. This research is part of the Academy of Finland funded project 127213.

\section{References}

Alvesson, M. (2001) 'Knowledge work: ambiguity, image and identity', Human Relations, Vol. 54, No. 7, pp.863-886.

Arvanitis, S. and Loukis, E. (2009) 'Information and communication technologies, human capital, workplace organization and labour productivity: a comparative study based on firm-level data for Greece and Switzerland', Information Economics and Policy, Vol. 21, No. 1, pp.43-61.

Bailey, D. and Kurland, N. (2002) 'A review of telework research: findings, new directions, and lessons for the study of modern work', Journal of Organizational Behavior, Vol. 23, pp.383-400.

Baruch, Y. (2000) 'Teleworking: benefits and pitfalls as perceived by professionals and managers', New Technology, Work and Employment, Vol. 15, No.1, pp.34-49.

Bélanger, F. (1999) 'Workers' propensity to telecommute: an empirical study', Information \& Management, Vol. 35, pp.139-153.

Bélanger, F. and Allport, C. (2008) 'Collaborative technologies in knowledge telework: an explanatory study', Information Systems Journal, Vol. 18, pp.101-121.

Bélanger, F. and Collins, R.W. (1998) 'Distributed work arrangements: a research framework', The Information Society, Vol. 14, pp.137-152.

Bentley, K. and Yoong, P. (2000) 'Knowledge work and telework: an explanatory study', Internet Research: Electronic Networking Applications and Policy, Vol. 10, No. 4, pp.346-356.

Beugelsdijk, S. and Van Schaik, T. (2005) 'Differences in social capital between 54 Western European regions', Regional Studies, Vol. 39, No. 8, pp.1053-1064.

Bourdieu, P. (1986) 'The Forms of Capital', in Richardson, J. (Ed.). Handbook of theory and Research for the Sociology of Education, Westport, Connecticut. 
Bourdieu, P. (2010) Distinction, Routledge, Cornwall.

Chalmers, L. (2008) 'Using IT in work at home: taking a closer look at IT use in home-located production', New Technology, Work and Employment, Vol. 23, No. 1-2, pp.77-94.

Cohen, L., Lawrence, M. and Morrison, K. (2007) Research methods in education, Routledge, Oxford.

Coleman, J. (1988) 'Social Capital in the Creation of Human Capital', The American Journal of Sociology, Vol. 94, pp.95-120.

Cooper, C. and Kurland, N. (2002) 'Telecommuting, professional isolation, and employee development in public and private organizations', Journal of Organizational Behavior, Vol. 23, pp.511-532.

Daniels, K., Lamond, D. and Standen, P. (2001) 'Teleworking: frameworks for organizational research', Journal of Management Studies, Vol. 38, No. 8, pp.1151-1185.

Dimitrova, D. (2003) 'Controlling teleworkers: supervision and flexibility revisited', New Technology, Work and Employment, Vol. 18, No. 3, pp.181-195.

Ellison, N. (1999) 'Social impacts: new perspectives on telework', Social Science Computer Review, Vol. 17, No. 3, pp.338-356.

Ellison, N., Steinfield, C. and Lampe, C. (2007) 'The benefits of Facebook 'friends:' social capital and college students' use of online social network sites', Journal of Computer-Mediated Communication, Vol. 12, No. 4, pp.1143-1168.

Florida, R. (2002) The rise of the creative class and how it is transforming work, leisure, community and everyday life, Basic Books, New York.

Florida, R. (2005) Cities and the creative class, Routledge, New York.

Florida, R., Mellander, C. and Stolarick, K. (2008) 'Inside the black box of regional development human capital, the creative class and tolerance', Journal of Economic Geography, Vol. 8, pp.615649.

Graham, M. (2011) 'Time machines and virtual portals: The spatialities of the digital divide', Progress in Development Studies, Vol. 11, No. 3, pp.211-227. 
Gravetter, F. and Wallnau, L. (2008) Essentials of statistics for behavioral sciences, Thomson Higher Education, Belmont.

Haddon, L. and Brynin, M. (2005) 'The character of telework and the characteristics of teleworkers', New Technology, Work and Employment, Vol. 20, No. 1, pp.34-46.

Hall, R. (2000) 'E-capital: The Link between the Stock Market and the Labor Market in the 1990s', Brooking Papers on Economic Activity, Vol. 2000, No. 2, pp.73-118.

Handy, S. and Mokhtarian, P. (1996) 'The future of telecommuting', Futures, Vol. 28, No. 3, pp. 227240.

Harmaakorpi, V. and Melkas, H. (2005) 'Knowledge management in regional innovation networks: the case of Lahti, Finland', European Planning Studies, Vol. 13, No. 5, pp.641-659.

Harpaz, I. (2002) 'Advantages and disadvantages of telecommuting for the individual, organization and society', Work Study, Vol. 51, No. 2, pp.74-80.

Helminen, V. and Ristimäki, M. (2007) 'Relationship between commuting distance, frequency and telework in Finland', Journal of Transport Geography, Vol. 15, pp.331-342.

Hoyman, M. and Faricy, C. (2009) 'It takes a village: a test of the creative class, social capital, and human capital theories', Urban Affairs Review, Vol. 44, No. 3, pp.311-333.

Inkinen, T. (2006) 'The social construction of the urban use of information technology: the case of Tampere, Finland', Journal of Urban Technology, Vol. 13, No. 3, pp.49-75.

Iyer, S., Kitson, M. and Bernard, T. (2005) 'Social capital, economic growth and regional development', Regional Studies, Vol. 39, No. 8, pp.1015-1040.

Jung, J., Qui, J. and Kim, Y. (2001) 'Internet Connectedness and Inequality', Communication Research, Vol. 28, No. 4, pp.507-535.

Kepsu, K. and Vaattovaara, M. (2008) Creative knowledge in the Helsinki Metropolitan Area: understanding the attractiveness of the metropolitan region for creative knowledge workers, AMIDSt, ACRE/WP5.5/REP.

Kirk, R. (2008) Statistics: an introduction, Thomson Higher Education, Belmont. 
Komninos, N. (2002) Intelligent cities, Spon Press, London.

Kurland, N. and Egan, T. (1999) 'Telecommuting: justice and control in the virtual organization', Organization Science, Vol. 10, No. 4, pp.500-513.

Laegran, A.S. (2008) 'Domesticating home anchored work: negotiating flexibility when bringing ICT based work home in rural areas', Geoforum, Vol. 39, pp.1991-1999.

Lai, Y. and Burchell, B. (2008) 'Distributed work: communication in an officeless firm', New Technology, Work and Employment, Vol. 23, No. 1-2, pp.61-76.

Lee, H., Shin, B. and Kunihiko, H. (2007) 'Telework vs. central work: a comparative view of knowledge accessibility', Decision Support Systems, Vol. 43, pp.687-700.

Lietsala, K. and Sirkkunen, E. (2008) Social media: introduction to the tools and processes of participatory economy [online]. University of Tampere, Hypermedia Laboratory Net Series 17. Available from: http://tampub.uta.fi/tup/978-951-44-7320-3.pdf. [Accessed 20 Nov 2011].

Lin, N. (1999) 'Building a Network Theory of Social Capital', Connections, Vol. 22, No. 1, pp.28-51.

Lorenzen, M. (2007) 'Social capital and localised learning: proximity and place in technological and institutional dynamics', Urban Studies, Vol. 44, No. 4, pp.799-817.

Mandarano, L., Mahbubur, M. and Steins, C. (2010) 'Building social capital in the digital age of civic engagement', Journal of Planning Literature, Vol. 25, No. 2, pp.123-135.

Mann, S. and Holdsworth, L. (2003) 'The psychological impact of teleworking: stress, emotions and health', New Technology, Work and Employment, Vol. 18, No. 3, pp.196-211.

Markusen, A. (2006) 'Urban development and the politics of a creative class: evidence from a study of artists', Environment and Planning A, Vol. 38, pp.1921-1940.

Putnam, R. (1993) 'The Prosperous Community. Social Capital and Public Life', The American Prospect, Vol. 13, pp.35-42.

Pyöriä, P. (2003) 'Knowledge work in distributed environments: issues and illusions', New Technology, Work and Employment, Vol. 18, No. 3, pp.166-180. 
Pyöriä, P. (2005) 'The concept of knowledge work revisited', Journal of Knowledge Management, Vol. 9, No. 3, pp.116-127.

Pyöriä, P. (2006) Understanding work in the age of information. Acta Universitatis Tamperensis, 1143.

Resnick, P. (2001) 'Beyond Bowling Together: SocioTechnical Capital', In Carrol, J. (Ed.). HumanComputer Interaction in the New Millennium, Addison-Wesley, Boston.

Rust, R. and Kannan, P. (2002) E-service: New Directions in Theory and Practice, Armonk, New York.

Rutten, B. and Boekema, F. (2007) 'Regional social capital: Embeddedness, innovation networks and regional economic development', Technological Forecasting \& Social Change, Vol. 74, pp.18341846.

Selwyn, N. (2004) 'Reconsidering Political and Popular Understandings of the Digital Divide', New Media Society, Vol. 6, No. 3, pp.341-362.

Shultz, T. (1961) 'Education and economic growth', in Henry, N. (Ed.), Social Forces Influencing American Education, The University of Chicago Press, Chicago, pp.46-88.

Stanworth, C. (1998) 'Telework and the information age', New Technology, Work and Employment, Vol. 13, No.1, pp.51-62.

Steinfield, C., Ellison, N. and Lampe, C. (2008) 'Social capital, self-esteem, and use of online social network sites: a longitudinal analysis', Journal of Applied Developmental Psychology, Vol. 29, No. 6, pp.434-445.

Sullivan, C. (2003) 'What's in a name: definitions and conceptualisations of teleworking and homeworking', New Technology, Work and Employment, Vol.18, No. 3, pp.158-165.

Svendsen, G., Kjeldsen, C. and Noe, E. (2010) 'How do private entrepreneurs transform local social capital into economic capital? Four case studies from rural Denmark', The Journal of SocioEconomic, Vol. 39, pp.631-644. 
Teixeira, A. and Fortuna, N. (2010) 'Human capital, R\&D, trade and long-run productivity: Testing the technological absorption hypothesis for the Portuguese economy, 1960-2001', Research Policy, Vol. 39, pp.335-350.

Thomsin, L. and Tremblay, D-G. (2008) 'Exploring the diversity of mobile working: a detailed examination on the sequences of workplaces and job satisfaction'. The Journal of E-working, Vol. 2, pp.61-80.

Tondeur, J., Sinnaeva, I., van Houtte, M. and van Braak, J. (2011) 'ICT as cultural capital: The relationship between socioeconomic status and the computer-use profile of young people', New Media Society, Vol. 13, No. 1, pp.151-168.

Toffler, A. (1980) The third wave, Bantam Books, New York.

Tremblay, D-G. and Darchen, S. (2010) 'The creative class thesis and the mobility patterns of knowledge workers considering the place of birth: the case of Montreal', International Journal of Knowledge-Based Development, Vol. 1, No. 3, pp.176-203.

Tura, T. and Harmaakorpi, V. (2005) 'Social Capital in Building Regional Innovative Capability', Regional Studies, Vol 39, No. 8, pp.1111-1125.

Vaattovaara, M. and Kortteinen, M. (2003) 'Beyond polarisation versus professionalization: a case study of the development of the Helsinki region, Finland', Urban Studies, Vol. 40, No. 11, pp.21272145.

van Deursen, A., van Dijk, J. and Ebbers, W. (2006) 'Why E-government Usage Lags Behind: Explaining the Gap Between Potential and Actual Usage of Electronic Public Services in the Netherlands', Lecture Notes in Computer Science, Vol. 4084, pp.269-280.

Wei, L. (2012) 'Number Matters: The multimodality of Internet Use as an Indicator of the Digital Inequalities', Journal of Computer-Mediated Communication, Vol. 17, pp.303-318.

Whittle, A. and Mueller, F. (2009) 'I could be dead for two weeks and my boss would never know': telework and the politics of representation', New Technology, Work and Employment, Vol. 24, No. 2, pp.131-143. 
Wilks, L. and Billsberry, J. (2007) 'Should we do away with teleworking: an examination of whether teleworking can be defined in the new world of work', New Technology, Work and Employment, Vol. 22, No. 2, pp.168-177.

Yigitcanlar, T., Baum, S. and Horton, S. (2007) 'Attracting and retaining knowledge workers in knowledge cities', Journal of Knowledge Management, Vol. 11, No. 5, pp.6-17. 
Table 1 Characters of the studied locations (region types, strata).

\begin{tabular}{|c|c|c|c|c|c|}
\hline & Population size & $\begin{array}{c}\text { Tertiary } \\
\text { educated } \\
\text { population }(\%)\end{array}$ & $\begin{array}{c}\text { Owner-occupied } \\
\text { housing }(\%)\end{array}$ & $\begin{array}{c}\text { Block houses } \\
(\%)\end{array}$ & $\begin{array}{l}\text { Average income } \\
\text { level per year } \\
(€)\end{array}$ \\
\hline $\begin{array}{l}\text { Region type I } \\
\text { City centre }\end{array}$ & 63972 & 46 & 41 & 97 & 42723 \\
\hline $\begin{array}{c}\text { Region type II } \\
\text { Detached house area }\end{array}$ & 10363 & 52 & 85 & 0.6 & 41232 \\
\hline $\begin{array}{c}\text { Region type III } \\
\text { Apartment block area }\end{array}$ & 21599 & 24 & 33 & 79 & 22372 \\
\hline
\end{tabular}

Table 2 Cross-tabulations and Spearman's chi-square test for educational level (1) and Mann-Whitney statistics for knowledge intensity and creativity (2) in the different groupings of teleworkers and nonteleworkers.

\begin{tabular}{|c|c|c|c|c|c|}
\hline & & $\begin{array}{c}\text { Home-anchored } \\
\text { workers, }(\%)\end{array}$ & $\begin{array}{l}\text { Mobile and part-time } \\
\text { teleworkers, }(\%)\end{array}$ & $\begin{array}{c}\text { Teleworkers, } \\
(\%)\end{array}$ & $\begin{array}{c}\text { Non-teleworkers, } \\
(\%)\end{array}$ \\
\hline 1) & Tertiary-educated & 62.5 & 73.3 & 71.7 & 50.0 \\
\hline & Others & 37.5 & 26.7 & 28.3 & 50.0 \\
\hline & P-value & \multicolumn{2}{|r|}{0.286} & \multicolumn{2}{|r|}{$<0.001$} \\
\hline \multirow[t]{2}{*}{ 2) } & Z & \multirow{2}{*}{\multicolumn{2}{|c|}{$\begin{array}{l}-0.17 \\
0869\end{array}$}} & \multirow{2}{*}{\multicolumn{2}{|c|}{$\begin{array}{l}-9.58 \\
<0001\end{array}$}} \\
\hline & P-value & & & & \\
\hline
\end{tabular}

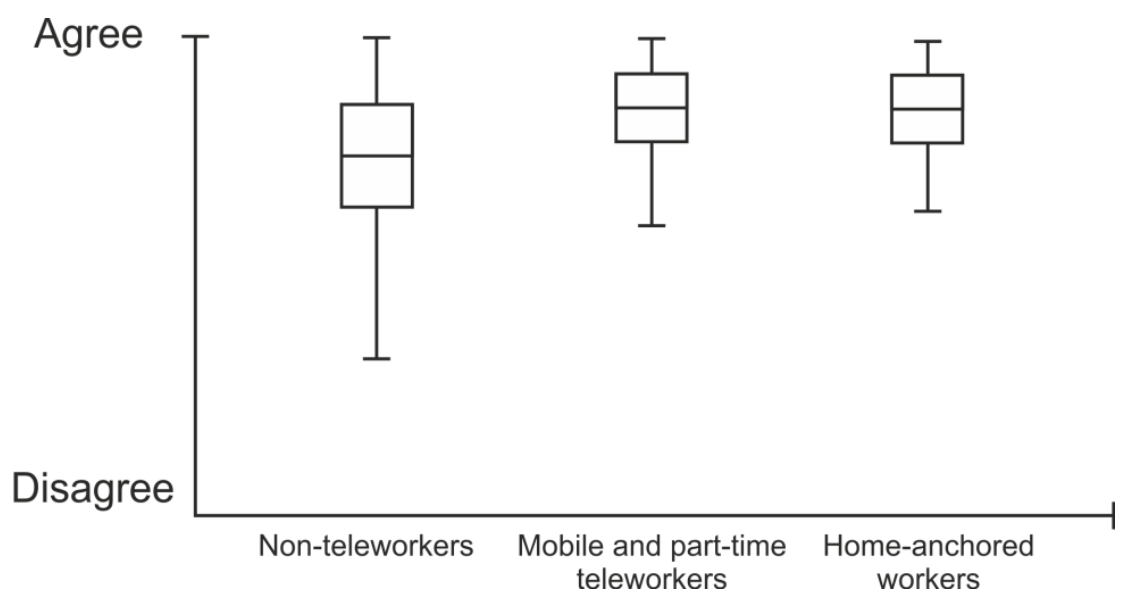

Figure 1 Knowledge intensity and creativity among teleworkers and non-teleworkers (extremes excluded). 
Table 3 Cross-tabulations and Spearman's chi-square test for e-capital measures (1-9) of the different groupings of teleworkers and non-teleworkers.

\begin{tabular}{|c|c|c|c|c|c|}
\hline & & $\begin{array}{c}\text { Home-anchored } \\
\text { workers, }(\%)\end{array}$ & $\begin{array}{l}\text { Mobile and part-time } \\
\text { teleworkers, }(\%)\end{array}$ & $\begin{array}{c}\text { Teleworkers, } \\
(\%) \\
\end{array}$ & $\begin{array}{c}\text { Non-teleworkers, } \\
(\%)\end{array}$ \\
\hline \multirow[t]{4}{*}{ 1) } & Use of a laptop daily $>4 \mathrm{~h}$ & 66.7 & 63.9 & 64.3 & 22.5 \\
\hline & Use of a laptop daily $<4 \mathrm{~h}$ & 21.2 & 22.8 & 22.5 & 36.9 \\
\hline & Use of a laptop < daily & 12.1 & 13.3 & 13.1 & 40.6 \\
\hline & P-value & \multicolumn{2}{|r|}{0.961} & \multicolumn{2}{|c|}{$<0.001$} \\
\hline \multirow[t]{4}{*}{ 2) } & Use of Internet daily $>4 \mathrm{~h}$ & 57.6 & 63.9 & 62.9 & 34.4 \\
\hline & Use of Internet daily $<4 \mathrm{~h}$ & 42.4 & 34.4 & 35.7 & 51.2 \\
\hline & Use of Internet < daily & 0.0 & 1.7 & 1.4 & 14.4 \\
\hline & $\mathrm{P}$-value & \multicolumn{2}{|r|}{0.467} & \multicolumn{2}{|c|}{$<0.001$} \\
\hline \multirow[t]{4}{*}{ 3) } & Use of email daily $>4 \mathrm{~h}$ & 42.4 & 40.6 & 40.8 & 21.9 \\
\hline & Use of email daily $<4 \mathrm{~h}$ & 54.5 & 54.4 & 54.5 & 53.2 \\
\hline & Use of email < daily & 3.0 & 5.0 & 4.7 & 24.9 \\
\hline & P-value & \multicolumn{2}{|r|}{0.912} & \multicolumn{2}{|c|}{$<0.001$} \\
\hline \multirow[t]{2}{*}{ 4) } & $\begin{array}{l}\text { Use of social networks sites } \\
\text { (SNSs) }\end{array}$ & 72.7 & 69.6 & 70.1 & 60.1 \\
\hline & P-value & \multicolumn{2}{|r|}{0.719} & \multicolumn{2}{|c|}{$<0.001$} \\
\hline \multirow[t]{2}{*}{ 5) } & $\begin{array}{c}\text { Use of SNSs for professional } \\
\text { networking }\end{array}$ & 47.8 & 58.5 & 56.8 & 26.6 \\
\hline & P-value & \multicolumn{2}{|r|}{0.234} & \multicolumn{2}{|c|}{$<0.001$} \\
\hline \multirow[t]{2}{*}{ 6) } & Use of LinkedIn & 26.1 & 46.3 & 43.2 & 18.4 \\
\hline & P-value & \multicolumn{2}{|r|}{0.07} & \multicolumn{2}{|c|}{$<0.001$} \\
\hline \multirow[t]{2}{*}{ 7) } & Use of Facebook & 95.7 & 84.6 & 86.3 & 90.2 \\
\hline & P-value & \multicolumn{2}{|r|}{0.155} & \multicolumn{2}{|c|}{0.202} \\
\hline \multirow[t]{2}{*}{ 8) } & Use of Twitter & 4.3 & 13.0 & 11.6 & 6.3 \\
\hline & P-value & \multicolumn{2}{|r|}{0.235} & \multicolumn{2}{|c|}{0.040} \\
\hline \multirow[t]{2}{*}{ 9) } & Use of Internet Forums & 36.4 & 32.6 & 60.7 & 51.8 \\
\hline & P-value & \multicolumn{2}{|r|}{0.690} & \multicolumn{2}{|c|}{0.031} \\
\hline
\end{tabular}


Appendix 1. Selected independent variable distributions in the data.

\begin{tabular}{cccccccccc}
\hline & Sample size & Respondents & Respondents (\%) & $\begin{array}{c}\text { Sex (\%) } \\
\text { W }\end{array}$ & $\begin{array}{c}\text { Tertiary educated } \\
\text { population (\%)* }\end{array}$ & $\begin{array}{c}\text { Owner occupied } \\
\text { housing (\%) }\end{array}$ & $\begin{array}{c}\text { Block } \\
\text { houses (\%) }\end{array}$ & $\begin{array}{c}\text { Household income } \\
\text { category per a year (€)** }\end{array}$ \\
\hline $\begin{array}{c}\text { Region type I } \\
\text { City centre }\end{array}$ & 1200 & 468 & 39 & 54 & 46 & 64.8 & 48.1 & 97.4 & $40000-59999$ \\
$\begin{array}{c}\text { Region type II } \\
\text { Detached house area }\end{array}$ & 500 & 220 & 44 & 59 & 41 & 53.2 & 89.1 & 0.9 & $80000-99999$ \\
$\begin{array}{c}\text { Region type III } \\
\text { Apartment block area }\end{array}$ & 800 & 283 & 35 & 58 & 42 & 32.9 & 45.9 & 66.4 & $40000-59999$ \\
$\quad$ In total & 2500 & 971 & 39 & 56 & 44 & 53 & 57 & 67 & $40000-59999$ \\
\hline
\end{tabular}

*Incomparable with Table 1, due to divergent classifications; **Median of the categorical variable 